\title{
Caught between a rock and a hard place: Social work in non-government organisations
}

\author{
Ashleigh Price and Stephanie Kelly Whitireia Community Polytechnic \& Wellington Institute of \\ Technology, Aotearoa New Zealand
}

\section{ABSTRACT}

INTRODUCTION: Non-government organisations (NGOs) make a significant contribution to social service delivery in Aotearoa New Zealand. The purpose of this research is to understand how government policy impacts social work practice in non-government organisations in Aotearoa New Zealand. How NGO social workers apply and maintain ethical principles and standards in the current socio-economic climate was explored. The study aimed to increase understanding of how NGO social workers remain dedicated to the pursuit of social justice and social change in their day-to-day practice, within conflicting policy environments and the government's social investment approach.

METHODOLOGY: A qualitative research methodology informed by a constructivist epistemology was adopted as the research strategy for this study. The interest was in exploring personal perspectives so qualitative in-depth interviews were carried out with five experienced NGO social work practitioners.

FINDINGS: Thematic analysis of the research data found that contemporary NGO social work is a practice characterised by a sense of powerlessness. From this sense of powerlessness, five sub-themes were identified: freedom and powerlessness; the application of the principle of social justice at a macro level; professional dissonance; issues of funding and resourcing constraints as a result of neoliberal economic policy; and finally, different realities and a notion of othering.

CONCLUSION: This research found that the social justice element of social work practice may be at risk should the dominant neoliberal social policy environment remain in existence.

KEYWORDS: Non-government organisations; social work; policy; social justice
According to Stats NZ (2018), of all the nonprofit activity groups, social services are the largest contributor to GDP and second largest in number of institutions, which include iwi and religious organisations. While non-profit organisations are deemed to be "in control of their own destiny" (Stats NZ, 2018, p. 7), this statement is contestable in the current socio-economic climate. Three decades of neoliberalism as a dominant social force in Aotearoa New Zealand have created an interesting and challenging environment in which to practise social work in the non-profit sector. Because neoliberalism highlights the value of free market competition, many non-government organisations (NGOs) have moved away from their values-based
AOTEAROA

NEW ZEALAND SOCIAL WORK 33(1), 67-80.

CORRESPONDENCE TO: Ashleigh Price ashleigh.price@whitireia. ac.nz 
agenda, applied a business model to their operations resulting in more competitive practices (Evans et al., 2005). The demands of managerialism, compliance, productivity measurement, accountability and risk aversion, otherwise stated as neoliberal ideology (Fenton, 2014; Hyslop, 2016; Stark, 2018) have influenced social work practice and social service delivery. Reliance on state funding has implications for NGOs' and social work's ability to challenge the decisions of policymakers. For many social workers, political-economics is the antithesis of why they entered the profession and often social workers do not appreciate, understand or realise the implications of such neoliberal policies on their work and on the lives of those whom they work with (Spolander et al., 2015; Stanley \& Kelly, 2018). The purpose of this research was to understand how government policy impacts social work practice in non-government organisations (NGOs) in Aotearoa New Zealand and to explore how NGO social workers apply and maintain ethical principles and standards in the current neoliberal socio-economic climate. It should be noted that the research was conducted during major national economic and social uncertainty regarding housing shortages.

Neoliberalism is a challenging concept. According to Mudge (2008), neoliberalism can be considered a "sui generis ideological system born of historical processes of struggle and collaboration in three worlds: intellectual, bureaucratic and political" (p. 704). At other times, neoliberalism is also referred to as economic Darwinism, free market fundamentalism or a theory of political economic practices (Giroux, 2010; Harvey, 2010; Thorsen \& Lie, 2006). For the purpose and context of this article, Hyslop's (2018) pragmatic summation of neoliberalism is fitting. Hyslop (2018) identifies neoliberalism as a set of values, ideas and practices, along with a "way of understanding and acting in the world that positions individuals to meet the needs of capital" (para. 3).
Aotearoa New Zealand has not escaped neoliberalism as a dominant social force, despite the image of our nation as an egalitarian Scandinavia of the Southern Hemisphere (Marcetic, 2017). Aotearoa New Zealand is recognised as where the welfare state originated (Belgrave, 2012; Kelsey, 1995), for being the first country to give women the vote, and for embracing diversity. However, socio-politically, it is now often known by what is referred to as the "New Zealand Experiment," whereby untested economic theories, informed by Thatcherism, became Aotearoa New Zealand government policy (Kelsey, 1995). Aotearoa New Zealand has continued to embrace neoliberalism as an ideology and policy model. During the Key government (2008 to 2017), public services were hollowed out in a quest for budget surpluses, slashing health funding, cutting support for education at all levels, and ramping up privatisation despite public objections (Marcetic, 2017). A social investment approach, adopted by the Key government in 2015, was based on the concept that government investment should be mediated on avoiding additional government investment in the future. This actuarial approach doubled down on Aotearoa New Zealand's neoliberal rationalities and governance but had little to do with helping disadvantaged people (Chapple, 2017).

Concerns over the impact of neoliberalism on social work are evident within the literature, suggesting that the implications of a neoliberal policy model range across comprehensive structural frameworks, from policy construction to consideration of values and concepts of practice (Wallace \& Pease, 2011). According to Morley and Macfarlane (2014), "neoliberalist discourses have infiltrated ethical standards in professional social work" (p. 337) and, although it is expected that social workers support practice that upholds social justice mandates, many reflect more of a commitment to a neoliberal agenda. Neoliberal changes to service delivery systems press social workers into 
emphasising the policing, compliance and accountability aspect of their work, rather than promoting social change capabilities, or reflecting the ethos and values of social work (Welbourne, 2011). This has flow-on effects, such as rewarding non-profits in the sector who deliver services for being competitive and compliant rather than transformative (Abramovitz \& Zelnick, 2015; Smith, 2007).

Within the Aotearoa New Zealand context, research indicates that that the current neoliberal framework for social work and social services has proved challenging (Humpage, 2019; Hyslop, 2013; O’Brien, 2009, 2016; Sawyers, 2016). Although a focus of social work is "to inform society at large about the injustices in its midst, and to engage in action to change the structures of society that create and perpetuate injustice" (Aotearoa New Zealand Association of Social Workers [ANZASW], 2019, p. 7), this may be easier said than done. The findings of Hyslop's (2013) study indicate that the profession of social work within a neoliberal framework continually contends with the paradoxical impression that its orientation is emancipatory, while the reality is otherwise. Although social work is dedicated to the achievement of social justice for all (ANZASW, 2019), the neoliberal agenda's preoccupation with efficiency and accountability poses a threat to both the commitment to the social justice mandate, and to service users themselves. Challenging social inequities and dominant discourses has been marginalised, replaced with conservative, individualised practices which mirror a neoliberal sense of personal responsibility, in which citizens are responsible for their own success-or lack of it (Kamali \& Jönsson, 2019).

\section{Method/research design}

To explore how social workers from NGOs were experiencing the national policy environment, the research project adopted a broad social constructivist ontological position, utilising an interpretivist approach which prioritised the voice and perspective of the participants. The research sample comprised four, female, registered NGO social workers and one female, nonregistered NGO social worker, recruited through the ANZASW website. A nonprobability sampling method was used to recruit these social workers. A purposive sampling technique then allowed the researcher to apply her own criteria when defining the sample, using judgement to select individuals for the study based on Ritchie and Lewis's (2003) strategy where "members of a sample are chosen with a purpose to represent a location or type in relation to the criteria" (p. 77). No male social workers responded to the recruitment invitation, therefore only women participated. The participants were required to have a minimum of two years' experience working in NGOs to ensure a depth of practice knowledge and an understanding of the non-profit sector. The five participants were practising in a variety of settings, including three large community-based social service providers, one church-based organisation and a health provider.

A qualitative, semi-structured interview process involving questions and discussion around the participants' experiences practising social work in an NGO was employed. Questions focused on how the social workers positioned their practice within the NGO sector, and how they experienced and managed tension as a result of broader neoliberal policy paradigms. Various key themes were identified using Braun and Clarke's (2006) six-phase guide to identify patterns or themes within the findings. The Whitireia-WelTec Postgraduate Board of Studies assessed this research as low ethical risk and provided approval for the research to proceed.

\section{Findings}

The findings of this research study were presented in line with the interview questions asked relating to the research question, "Does government policy impact on social work practice in NGOs?" The main, overarching 
theme extrapolated from the findings of this study was the deep sense of powerlessness experienced by the participants in their day-to-day practice. Five sub-themes were also identified. These were: freedom and powerlessness; the application of the principle of social justice at a macro level; professional dissonance; issues of funding and resourcing constraints as a result of neoliberal economic policy; and policy imperatives and realities; and a notion of othering. Although each sub-theme is distinct from the others, there is a clear relationship between them-the overarching theme of powerlessness, with each theme implicitly entwined with the others in this regard.

\section{Powerlessness}

The word powerlessness was not overtly used by the participants, but it was clear that these social workers experienced feelings of powerlessness which were ubiquitous and pervasive.

I've experienced things that I've never experienced before in that you can't help people. You can't help people ... It's changed the way I work. Sometimes I work with people with less optimism than I did because for that person I am going to do my best, but I don't think there's going to be a lot to change their situation. (Participant One)

You really feel like the power that we had has been depleted because the resources aren't there for people. (Participant One)

Powerlessness related to the social workers' feelings of not being able to access adequate resources, change situations or actually do their jobs well. It was particularly evident when the practitioners discussed housing insecurity in Aotearoa New Zealand. The housing crisis was seen as a structurally imposed issue that there was no solution to within the social workers' realms of influence, suggesting an impotency to promote change at a macro level. Societal change at a more macro or government policy level appeared not to be an intervention the social workers felt able to undertake and was not identified as an option. The social workers exhibited a passive acceptance of their clients' precarious housing situations and a sense of resignation to the situation being out of their hands, deeming it to be a structural issue and one which is left to others to address. Instead, they chose to concentrate on individualised micro practice. One social worker stated, "it's frustrating and worrying, but it's an issue I can't do anything about" (Participant Four). The challenges faced by clients were seen by the practitioners as the consequence of what was perceived to be poor policy decisions by policymakers who were seen to retain control over determining how help was given to those individuals in need.

Particularly noteworthy was the apparent extension of who the powerless were-from clients or users of services, to the inclusion of the NGO social workers themselves. The social workers in this study frequently referred to a lack of funding, resourcing, and the very low rates of pay they received in their NGOs. These challenging working conditions appeared to contribute to the feelings of powerlessness they experienced. All the practitioners talked about the effects on their practice of working with minimal resources over a 10-year period, and the consequent sense of powerlessness to practice as wholly as they would like to. The powerful "others" the social workers appeared to hold responsible for their powerlessness were policymakers, staff from government ministries, particularly the Ministry of Social Development, funding agencies, and government itself.

\section{Freedom}

Interestingly, while powerlessness in their practice was a central theme, when discussing working at a non-government social service agency, the participants also described experiencing freedom. One practitioner illustrated their experiences of freedom by stating: 
I've actually really, really enjoyed it, simply because we've got a little bit more freedom than you would if you were in a statutory organisation of some kind. (Participant Four)

The freedom the social workers spoke of, however, was experienced at an organisational level, or coal-face level, as distinguished from the wider structures they identified as leaving them feeling powerless. The social workers identified their capacity to self-manage, freedom from supervisory scrutiny and a high level of selfdetermination in their decision-making and interventions with clients. The social workers measured the freedom they experienced by comparing their work environments with what they perceived to be the tightly prescribed boundaries, time constraints, and management measures experienced by statutory social workers.

These findings suggest the perceived freedom the practitioners experienced was restricted to certain aspects of their individual practice, such as the freedom to conduct the normative daily activities and apply professional discretion regarding their clients. However, their experiences of freedom did not appear to extend beyond this individualised practice to the broader organisational level. Contractual parameters and eligibility criteria for services were identified as dictated by the funding agencies, and as limiting the practitioners' freedom to assist and work with clients in the way they wished to. Although the social workers showed that they made work-related decisions on the basis of their professional knowledge and values, they were very clear that they were subject to the directives of those outside the profession and to constraints that were inconsistent with their professional social work knowledge and values (Weiss-Gal \& Welbourne, 2008). They attributed these constraints as coming from outside funding agencies and policymakers. The practitioners identified that they exercised the freedom they experienced, which they deeply valued, within a framework of accountability. This reflects the premise that neoliberal governance promotes individual autonomy while at the same time contradicting social work's commitment to social justice through high levels of accountability and efficiency.

This reinforces the larger professional challenges of "sustaining the social work discourse in the current socio-economic climate" (Hyslop, 2016, p. 8).

\section{Social justice principles}

Contrary to expectations, the theme of social justice, an integral part of a social worker's value set, was not really part of their deliberations regarding their role. Social justice, a key ethical principle which guides social worker's pursuit of social change, was, surprisingly, left largely undiscussed throughout the interviews. It simply did not arise as an area of concern for the participants, in spite of the purposeful crafting of interview questions designed to encourage discussion around the social workers' experiences and what informs their practice.

For most of the participants, understanding what informed their practice was challenging to articulate. The social workers referred to a complex and interacting mix of practice experience, social work theory, professional development, policy and funding requirements, and community need as suffusing their practice. The core value of promoting social justice was only vaguely touched on by one practitioner as a possible future practice focus.

This finding suggests that the social workers in this study did not feel that challenging wider, systemic social injustices was part of their remit, leaving difficult issues such as housing insecurity to unidentified others to address. Paradoxically these others appeared to be the government institutions the social workers identified as being complicit in creating oppressive structural challenges. This point is evidenced by the statements of two social workers in this study. One social worker 
stated, "I can't carry what is essentially a structural problem" (Participant One). Another stated, "I'm stuck, there's not a lot I can do" (Participant Five). Fighting for change at the macro level was not a priority, and indeed, an air of resignation prevailed. The rise of neoliberal ideology within public services has led to an emphasis on bureaucracy and micro-interventions, with social work practice confined to the individual level, rather than challenging those structures that create oppression (Rogowski, 2020). The practitioners' evident powerlessness to apply a critical lens to societal conditions is concerning given the need for purposive and structural change rather than merely the amelioration of individual issues (Reisch, 2016).

\section{Professional dissonance}

Professional dissonance, characterised as "an experience of discomfort arising from the conflict between professional values and job tasks" (Taylor, 2002, p. 36), appeared to be experienced by the social workers interviewed. Tension, ambivalence, and incongruity were significant features of their everyday professional lives.

Participant Two, who worked for a government-funded emergency and social housing provider primarily working with those experiencing housing insecurity, offered a practical example of the professional dissonance she experienced in her practice. Initially she stated unequivocally that, in her practice, the ANZASW Code of Ethics "overrides everything else". She clearly asserted, "if it doesn't match up with my ethical obligations then I am not doing it." However, she went on to offer an example of how the rights of clients and the ethical obligations of social workers can be superseded by the compliance demands of government agencies. This social worker described an agonising ethical practice quandary whereby she was forced to screen clients and refuse services to those individuals with more complex needs, to ensure her organisation met Ministry of Social Development prescribed targets:

... you get smarter at the beginning and that's a terrible decision to have to make but what I'm saying is that if you were just talking about numbers then you have to be smarter at the beginning to get the output that you want ... which is terrible and you shouldn't as a social worker, I shouldn't have to do that, it should be who's got the greatest need ... if you haven't met your numbers you won't get your contract again and I think that's really sad. (Participant Two)

The method described is known as cherry picking, an exclusionary practice whereby clients with the highest needs are perceived as non-viable or too difficult to meet government prescribed targets and outcomes. Here we see evidence of contemporary social work's subjection to competing demands and conflicting values systems-those of the social work profession and those of the powerful dominant forces that direct social service delivery. The dilemmas faced in their dayto-day practice highlight the practitioners' powerlessness to maintain the social work discourse in any meaningful way.

\section{Lack of funding and resourcing}

A lack of funding and resourcing also impacted the social workers on both a personal and a professional level. The word funding arose 47 times throughout the interviews, so was a significant theme in this study. On a personal level, the social workers indicated that reconciling their love of their jobs with low rates of pay, poor resourcing, inadequate funding, and consequent feelings of being undervalued was a constant. This is evidenced by the following statements:

... we stay because we are passionate about the work that we do and about helping people, and I mean, I didn't go into social work for the money, but the reality is, you know, you need money to survive... (Participant Two) 
Another participant stated, "we just never get good salary increases ... our pay just doesn't go up ... it affects us on a personal level" (Participant Three).

All the social workers spoke of their feelings of being fiscally undervalued. When they discussed this, it was in one of two ways. For some, it was in a fatalistic manner, indicating a sense of resignation to change their current situation. Others overtly expressed frustration and anger at the disparity between their working conditions and salaries, and what they perceived to be the better working conditions and salaries of the government workers creating the polices they were required to apply. One social worker described her work conditions and pay as:

... shocking! In a bad way, just the level of ... lack of resourcing and not nearly, not as good systems or not as good management, not as good leadership, not good working conditions. I've been quite astounded at the conditions in which people work actually. It's a real contrast you know. (Participant Three)

Situated within this theme, the issue of mandatory reporting requirements for the government agencies arose. These reporting requirements appeared to be a source of dissension for these practitioners. The frustration the social workers expressed at the amount of time they spend on administrative requirements, such as the need to provide extensive personal information about their clients, was evident:

People are entitled to that privacy, you wouldn't ask a government minister to give their personal information like that, why are you expecting someone, because they've got nothing, to have to give personal information to someone who's just going to use it how they're going to use it. (Participant Four)

The participants explained that administrative requirements for the funding agencies had increased over the past ten years. They all expressed their frustration at spending so much time on "paperwork" for what they perceived to be "statistical purposes." One social worker explained that she would set aside an entire day each week for administration duties, stating, "it's ridiculous" (Participant Two). Another social worker identified that she spends less time with her clients and more time on administration, impacting her direct practice:

Now we spend more time on admin, we spend more time emailing people, we spend more time phoning people, we spend more time you know solving sort of problems away from the client. I used to in the past ... I probably would have done things when I was there in the home, and with the client supporting them to do it, but now I have to do more for them because I haven't got time to do that ... I've got less time to be with them, helping them do things and maintaining their independence as much as possible... (Participant Three)

The participants' experiences of a preoccupation with measuring, quantifying and evaluating processes in a bid for efficiency can be defined as a "tyranny of metrics" (Muller, 2018), threatening direct practice and undermining social workers' ability to promote client kawanatanga. The practitioners' experiences reflect Freidson's (2001) ideology of managerialism which claims that a managerialist approach "denies authority to expertise by claiming a form of general knowledge that is superior to specialization because it can organize it rationally and efficiently" (pp. 116-117), potentially leading to a shift in the very essence of the profession.

\section{Policy, reality and "othering"}

The final theme is of a disconnect between what the participants refer to as "reality" and what policymakers understand to be reality, resulting in an "othering" phenomenon. The social workers in this study suggested 
that the policies they were compelled to mediate were, at times, not fit for purpose. The implication was that policymakers are too far removed from the situations the policies are meant to address, and therefore do not comprehend the reality for the service user and the challenges for the practitioner working within the social policies they are developing:

This lady [from MSD] ... was just like, wow, you know it is so different to be able to talk to somebody who is dealing with things firsthand.

The participant goes on to say:

... any kind of interaction between policymakers in government and social workers, you know, they don't understand the actual reality of what it is like and what is actually going on with people. I think sometimes it is easy when you're in your office or wherever and you're not really seeing the guts of what's going on. (Participant Two)

The word reality was used frequently by the social workers throughout the interviews, in particular when discussing what they perceived to be societal need and what they understood to be a lack of understanding of this need by the government agencies that create policy. This disparity frustrated the social workers, with references made to policymakers "sitting in offices." The social workers advised that, on the infrequent occasions they spoke with policymakers, the government employee typically appeared to have little concept of what the social workers did, how the policies they developed were mediated, or any depth of understanding about the lived realities of service users. The social workers spoke of a lack of communication, identifying that they were rarely included in direct dialogue with policymakers.

Although not explicitly stated, the social workers in this study experienced a subtle form of oppression by those they considered to hold the power, i.e., policymakers. Feelings of exclusion, devaluation, and unequal treatment both fiscally and professionally were alluded to, pointing to the evolution of a them-us dichotomy as a result of being perceived as inferior to those holding more power. One of the social workers in this study expressed extreme frustration in this regard, illustrated in the following statement:

I get a bit angry ... I thought, there's so many people that work in this organisation (MSD) making policy and what are they doing and why are they all kind of like, why is there so much money going into this and we're really, our organisation is struggling to pay us a decent wage. (Participant Three)

\section{Discussion}

Several salient conclusions for the social work profession can be inferred from this small study. By interviewing social workers from the NGO sector working in a neoliberal policy environment, key challenges that they expressed should be noted by others in the wider field of social work provision in this country. In particular, barriers to ethical and principled social work practice in the NGO sector in Aotearoa New Zealand exist. Social justice imperatives are shown to be sidelined in the pursuit of more managerial practices. This results in workers at the coalface feeling a sense of powerlessness at their lack of inclusion in the policymaking process.

\section{The paradox of power(lessness) and freedom}

While this concept of powerlessness is a central theme permeating this study and can be directly attributed to changing ideological agendas of governments over the past ten years, there was also a sense of individual freedom in their day-today work with clients. Thus, a paradox emerges. Powerlessness originates from an inability to enact choices and exposure to the disrespectful treatment that results 
from occupying a marginal status and is most likely to be experienced when there is a rift between those exercising power and decision-making authority (Barnes \& Mercer, 2004; Young, 1990). While this explanation may be a fitting description of the experiences of social work service users, it can also be applied to the social workers themselves.

Although the social workers' experiences of disempowerment were often subconscious, their satisfaction around the freedom they experienced was overt. The concept of freedom the social workers discussed is a beguiling, yet contradictory one, characterized as individual or personal freedom. According to Hayek's (1960) philosophy of freedom, concern for the public good is contradictory to the greatest good of individual freedom. As such, it could be argued that the practitioners' perceptions of freedom arise from a neoliberal ideology which emphasises individualism, perpetuating policies of personal accountability, self-advancement and free enterprise, rather than shared obligation, collectivism and citizenship. This individualisation reflects a political preoccupation with personal responsibility and the preeminence of the individual, exemplified by the social investment approach adopted by the previous National-led government (O'Brien, 2016). Paradoxically, NGO social work's call for improved government funding may lead to increased compliance and accountability requirements, constraining the much-enjoyed freedom the social workers experience. This micro-level approach may limit a big-picture perspective that enables social workers to collectively focus on the prevention of problems by promoting structural solutions to oppression (Reisch, 2016).

\section{Promotion of social justice is hypothetical}

The global definition of the social work profession developed by the International Federation of Social Workers (IFSW) (2014) states that principles of social justice, human rights and collective responsibility are central to social work. This definition highlights the importance of social justice to the practice of effective social work (O'Brien, 2013). The IFSW (2019) states that "social workers must challenge employers, policymakers, politicians and civil society, situations where policies and practices are socially unjust" (p. 2). Therefore, the limited references by participants to a social justice imperative is noteworthy, suggesting the possibility that the social workers find applying this principle challenging. This premise supports Strier and Breshtling's (2016) proposition that social workers are now, more than ever, expected to interpret and enforce the regulation of behaviours by the state, a practice that challenges any attempt at applying the social justice obligation of the profession. It also supports O'Brien's (2009) assertion that without explicit attention to social justice, social work becomes "something else."

Participation in decision-making at a policy level does not appear to be within these social workers' frames of reference and may not be realistically feasible within the parameters of the current relationship with funders and policymakers. A binary understanding of power may go some way to explaining the social workers' lack of participation at a macro level. According to Fook (2007), "individuals can participate in their own domination, by holding self-defeating beliefs about their place in the social structure, their own power, and possibilities for change" (p. 445). The practitioners' reluctance to challenge oppressive dominant social structures suggests that perhaps a contemporary social work practice worldview now exists, whereby social workers in Aotearoa New Zealand observe social issues at a depoliticized distance. This may suggest a shift in the social work agenda. Challenging social injustices, particularly those policies that undermine human rights, is not an easy task and may consequently often be reduced to rhetoric (Morley \& Ablett, 2017). The level of access by service 
users to necessary resources such as secure housing is what determines the degree of ability for social workers to effect change; if these resources are not readily available, the ability of social workers to influence the macro socioeconomic structure or have the capacity to effect policy change is diminished (Sadan, 1997).

While it could be assumed that most social workers would agree in principle with core values such as social justice and challenging unjust policies and practices, the social workers' lack of emphasis on a social justice mandate at a macro level substantiates Morley's (2016) suggestion that many conventional social work practices, when critically analysed, "reflect more of a commitment to being aligned with the systems that create injustice, rather than supporting the people who are disenfranchised by them" (p. 42). The type of social work that fulfils its ethical mandate, as set out in the IFSW Global Social Work Statement of Ethical Principles (2018), has been termed critical/radical social work (Ferguson, 2009; Hyslop, 2016; Morley, 2016). According to Morley and Ablett (2017), radical social work challenges the social structures that disadvantage, and can lead social work through its capacity to analyse the socio-economic-political context that produces oppression. This type of critical/ radical practice, according to Stark (2018), is merely meeting the pre-neoliberal social work imperative of being socially critical, political practitioners who challenge and influence the macro structures in society, and so participate in the development of social policy.

In the context of this study, the social workers' ethical code gives them both authorisation and obligation to challenge issues of social injustices; however, there is little evidence of enactment of this ethical requirement in practice, especially at the macro level. This may suggest the need for what Morley et al. (2014) identify as a social work approach which supports and advocates for social reform, challenges current society and pursues social justice and human rights.

\section{Forced compliance in a neoliberal world}

Social work is a profession characterised by difficult decision making, conflicting beliefs and values and often dichotomous professional roles. Consequently, the pressure to meet contractual obligations may encourage some social workers to adopt exclusionary practices such as choosing to work with easier-to-assist clients (Aronson \& Smith, 2010). The professional dissonance experienced by the social workers in this study substantiates Hyslop's (2013) research findings which suggest that maintaining the social work discourse in a neoliberal environment is difficult, with social workers experiencing pressure to move closer to the demands of the system and further from the needs of the client.

This study demonstrates the co-option of social work into neoliberalism. The professional dissonance associated with meeting obligations to the funding agency rather than addressing the needs of the most vulnerable in our communities is referred to by Foucault as the "governmentalization of the state" (1991, p. 103). Weber's (1946) theories of rationalization (1864-1920) may also offer insight into the social workers' feelings of dissonance, suggesting that values once entrenched in an ethical context are lost in society, with rational calculation and efficiency prioritised over a more sympathetic and harmonious society. Powerful decision-making by policymakers supplant regard for individuals, prioritizing rule-following and efficiency (Tsakiris, 2018).

The previous National-led government's social investment framework embraced the nascent neoliberal policy setting and endorsed the gathering of ICT-based output data, suggesting that social work principles have been relegated in favour of managerial accountabilities (Burton \& van den Broek, 2009; Hyslop, 2016). Efficiency-focused organisations have been "increasingly attracted by the promise of output and outcome measures associated 
with scientised 'evidence-based' approaches to social work practice" (Hyslop, 2013, p. 15), with expanding government contracts requiring social service agencies to provide comprehensive outcomes-based data based on homogeneous measurement processes (Abramovitz \& Zelnick, 2015). Indeed, the accounts of the social workers in this study substantiate Smith's (2011) assertion that neoliberal policy and processes effectively stymie many options for emancipatory practice and the pursuit of social change.

The experiences of the social workers in this study support the notion that contemporary social work is no longer a values-based, social justice focused profession (Hyslop, 2012). For NGO social work, the political challenge of neoliberalism may necessitate a redefinition of practice principles away from those ideological values that once were attainable, to a more realistic set of guidelines. Regrettably, these economic policy models that embrace free-market capitalism have become entrenched, with the hegemonic nature of neoliberalism left unchallenged, and although not accepted as ideal or desirable, neoliberal governing practices may need to be seen as necessary or inevitable (Skilling, 2016; Wallace \& Pease, 2011).

\section{A disconnected sector}

A disconnect between what the social workers in this study refer to as reality and what policymakers understand to be reality is evident. The subordination and oppression experienced by the social workers in this study can be described as othering-a complex process of attitudes and behaviours embedded in an inegalitarian societal worldview that is constantly affirmed and reproduced through institutional practices, cultural norms, and individual actions that treat some people as superior and others as inferior (Dominelli, 2002).

The suggestion that there exists a disconnect between social workers' and policymakers' perceived realities, and the perceived disparity between working conditions and rates of pay resulting in this othering phenomenon, is consistent with aspects of Cribb's (2017) research. Cribb found that there has been a deterioration in the relationships NGOs have with government funders, with NGOs becoming increasingly mistrustful of government agencies. Cribb's research suggests that funders require good knowledge of the needs of the communities they are serving, and that this is unlikely to occur from a desk in Wellington or through a paper-based reporting relationship. As to communication between social workers and policymakers, Mosley (2017, as cited in Sheehy, 2017) suggests that, frequently, the feedback loop is broken between the officials who make decisions about the policies and the agencies responsible for implementing the policies. Policymaking would likely be more effective if the nonprofit social service providers had a seat at the table. For the most part however, they are strikingly absent from the policymaking process (Cribb, 2017).

According to Maidment and Beddoe (2016), "social work is about fostering social change, and this entails understanding the social policy milieu in which these change efforts occur" (p. 21). Because social policy underpins the legislative framework that social workers function within, it is important for practitioners to understand more about the development and rationale behind policymaking, otherwise social workers may unintentionally reinforce flawed policies as a result of not applying a social justice lens to their practice (Popple, 2017; Powell et al., 2013). Robust social policy that responds to the disparities and inequities in our society can and should be informed by the experts in the field-social workers.

\section{Conclusion}

The impact of macro-economic neoliberal policy is far-reaching and has implications for social welfare and social work practice. This study highlights that neoliberal macroeconomic policy has been embedded so pervasively in Aotearoa New Zealand 
that it is difficult for social workers to articulate an alternative vision for their profession, particularly in non-government organisations. In essence, they carry out the work of the state, possibly saving the state money. NGOs' reliance on state funding for survival means that challenging government-imposed policies or directives that do not align with the guiding principles of the social work profession is dangerous as funding may not continue.

This results in the social justice element of social work practice being put at risk, should the dominant neoliberal social policy environment remain in existence. While the social workers in this research demonstrated insight, acknowledging the existence of structural inequities and the influence of socio-economic and political factors as barriers to service users' wellbeing and development (IFSW, 2018), there was no strategy articulated to address these structural barriers or attempts to transcend the micro-macro divide. In short, current social work practices fail to uphold the social change mandate or challenge social injustice, including government policies that harm wellbeing. That said, the small size of the sample means the perspective of these practitioners may not be representative of all NGO social workers. Another limitation to consider is that the research was conducted at the height of the housing crisis, which dominated the interviews conducted. The interviews were conducted shortly after a change of government, consequently further contemporary research on this topic is recommended. It is also recommended that the Social Workers Registration Board promote macro practices, particularly those related to social justice. Social work educators should enhance students' understanding of macro practice, reexamining curricula to ensure the inclusion of critical social work contexts.

Hyslop (2012) suggests that social work is often experienced and described as tricky work, ascribing the terms "risky, uncertain, precarious, unpredictable, dangerous, contradictory, ambiguous, contingent, conflicted and complex" to this profession (p. 414). This research supports this premise, emphasising the Janus-faced and contradictory nature of social work in non-government organisations. These practitioners are caught between a rock and a hard place.

Accepted 4 November 2020

Published 25 April 2021

\section{References}

Abramovitz, M., \& Zelnick, J. (2015). Privatization in the human services: Implications for direct practice. Clinical Social Work Journal, 43(3), 283-293. https://doi. org/10.1007/s10615-015-0546-1

Aotearoa New Zealand Association of Social Workers. (2019). About us. https://anzasw.nz/about-us/

Aronson, J., \& Smith, K. (2010). Managing restructured social services: Expanding the social? British Journal of Social Work, 40(2), 530-547.

Barnes, C., \& Mercer, G. (2004). Implementing the social model of disability: Theory and research. The Disability Press.

Belgrave, M. (2012, December). Social policy history: Forty years on, forty years back. [Presentation]. Affording our Future Conference, Wellington. https://www.victoria. ac.nz/sacl/centres-and-institutes/cpf/publications/ pdfs/1.8-Belgrave-paper.pdf(external link)

Braun, V., \& Clarke, V. (2006). Using thematic analysis in psychology. Qualitative Research in Psychology 3, 77-101. doi:10.1191/1478088706qp063oa

Burton, J., \& van den Broek, D. (2009). Accountable and countable: Information management systems and the bureaucratization of social work. The British Journal of Social Work, 39(7), 1326-1342. https://doi.org/10.1093/ bjsw/bcn027

Chapple, S. (2017). What should the new government do about social investment? https://www.wgtn.ac.nz/igps/ commentaries/what-should-the-new-government-doabout-social-investment

Cribb, J. (2017). Governing for good: The governance capability of social service NGOs. http://www. communityresearch.org.nz/wp-content/uploads/ formidable/8/Governing-For-Good-Report-Jo-Cribb-1.pdf

Dominelli, L. (2002). Anti-oppressive social work theory and practice. Palgrave.

Evans, B., Richmond, T., \& Shields, J. (2005). Structuring neoliberal governance: The nonprofit sector, emerging new modes of control and the marketisation of service delivery, policy and society. Policy and Society, 24(1), 73-97. doi:10.1016/S1449-4035(05)70050-3

Fenton, J. (2014). Can social work education meet the neoliberal challenge head on? Critical and Radical Social Work, 2(3), 321-335. 
Ferguson, I. (2009). Another social work is possible! Reclaiming the radical tradition. In V. Leskoše (Ed.), Theories and methods of social work: Exploring different perspectives (pp. 81-98). University of Ljubljana Faculty of Social Work.

Fook, J. (2007). Reflective practice and critical reflection. In Lishman, J. (Ed), Handbook for Practice Learning in Social Work and Social Care (pp. 440-454) Jessica Kingsley.

Foucault, M. (1991). Governmentality. In G. Burchell, C. Gordon, \& P. Miller (Eds.), The Foucault effect: Studies in governmentality (pp. 87-104). Harvester Wheatsheaf.

Freidson, E. (2001). Professionalism: The third logic. Polity.

Giroux, H. (2010). Public values, higher education and the scourge of neoliberalism: Politics at the limits of the social. Cultural Machine, 1-18.

Hayek, F. A. (1960). The constitution of liberty. University of Chicago Press

Harvey, D. (2010) A Brief History of Neoliberalism. Oxford University Press.

Humpage, L. (2019). How do beliefs and institutional context influence the portability of political and civil society behaviours among New Zealand return migrants? Journal of Sociology. doi:10.1177/1440783319888294.

Hyslop, I. (2012). Social work as a practice of freedom. Journal of Social Work, 12(4), 404-422. https://doi. org/10.1177/1468017310388362

Hyslop, I. (2013). Social work practice knowledge: an enquiry into the nature of the knowledge generated and applied in the practice of social work. [Unpublished doctoral dissertation, Massey University]. http://mro.massey. ac.nz/handle/10179/5139

Hyslop, I. (2016). Neoliberalism and social work identity. European Journal of Social Work, 1-12. https://doi.org/1 $0.1080 / 13691457.2016 .1255927$

Hyslop, I. (2018). Social well-being: A radical change of course or soft neoliberalism? Reimagining Social Work in Aotearoa New Zealand. Retrieved April 1st 2021 from http://www.reimaginingsocialwork.nz/2018/12/ social-well-being-a-radical-change-of-course-or-softneoliberalism/\#more-2608

International Federation of Social Workers. (2014). Global social work statement of ethical principles. https:// www.ifsw.org/global-social-work-statement-of-ethicalprinciples/

International Federation of Social Workers European Region E.V. (2018). Standards in social work practice meeting human rights. http://cdn.ifsw.org/assets/ifsw_92406-7.pdf

Kamali, M., \& Jönsson, J. H. (2019). Revolutionary social work: Promoting sustainable justice. Critical and Radical Social Work, 7(3), 293-314.

Kelsey, J. (1995). Economic fundamentalism: The New Zealand experiment: $A$ world model for structural adjustment? Pluto Press.

Maidment, J., \& Beddoe, L. (2016). Social policy, social work and social change. In J. Maidment \& L. Beddoe (Eds.), Social policy for social work and human services in Aotearoa New Zealand: Diverse perspectives (pp. 21-33). Canterbury University Press.

Marcetic. B. (2017). New Zealand's neoliberal drift https://www.jacobinmag.com/2017/03/new-zealandneoliberalism-inequality-welfare-state-tax-haven/
Morley, C. (2016). Promoting activism through critical social work education: The impact of global capitalism and neoliberalism on social work and social work education. Critical and Radical Social Work. https://doi.org/10.1332/ 204986016X14519919041398

Morley, C., \& Ablett, P. (2017). Rising wealth and income inequality: A radical social work critique and response. Aotearoa New Zealand Social Work, 29(2), 6-18.

Morley, C., \& Macfarlane, S. (2014). Critical social work as ethical social work: using critical reflection to research students' resistance to neoliberalism. Critical and Radical Social Work, 2(3), 337-355.

Morley, C. Macfarlane, S. \& Ablett, P. (2014). Engaging with Social Work: A critical introduction. Port Melbourne.

Mudge, S. L. (2008). The state of the art: What is neoliberalism? Socio-Economic Review, 6(August), 703-731. https://doi.org/10.1093/ser/mwn016

O'Brien, M. (2009). Social work and the practice of social justice: An initial overview. Social Work Review, (1\&2), 3-10.

O’Brien, M. (2013). Social work registration and professionalism: Social justice and poverty - fellow travellers or discarded passengers? Aotearoa New Zealand Social Work Review, 25(3), 50-59.

O'Brien, M. (2016). The triplets: Investment in outcomes for the vulnerable-reshaping social services for (some) New Zealand children. Aotearoa New Zealand Social Work, 28(2).

Popple, K. (2017). Social policy for social work: Placing social work in Its wider context. The British Journal of Social Work, 47, (1), 279-281. https://doi.org/10.1093/bjsw/ bcw120), 9-21.

Powell, T. J., Woodford, M. R., Perron, B. \& Garrow, E. (2013). Policymaking opportunities for direct practice social workers in mental health and addiction services. Advances in Social Work, 14(2), 367-378.

Reisch, M. (2016). Why macro practice matters. Journal of Social Work Education, 52(3), 258-268.

Ritchie, J., \& Lewis, J. (2003). Qualitative research practice: A guide for social science students and researchers. Sage Publications.

Rogowski, S. (2020). Critical and radical social work practice in neoliberal times. http://www.transformingsociety. co.uk/2020/08/25/critical-and-radical-social-work/

Sadan, E. (1997). Empowerment and community planning: Theory and practice of people focused social solutions [in Hebrew]. Hakibbutz Hameuchad Publishers.

Sawyers, L. (2016). Finally accountable? Social work and the community investment strategy. Aotearoa Social Work, 28(2), 32-39. https://anzswjournal.nz/anzsw/article/ viewFile/222/293

Sheehy, M. (2017). Exploring the disconnect between policy makers and service providers. School of Social Service Administration Magazine, 24(1). https://ssa.uchicago. edu/ssa_magazine/exploring-disconnect-between-policymakers-and-service-providers

Skilling, P. (2016). Neoliberalism, public policy and public opinion. New Zealand Sociology 31(7), 159-182.

Smith, K. (2007). Social work, restructuring and everyday resistance; "best practices" gone underground. In D. Baines (Ed.), Doing anti-oppressive practice: Building transformative politicized social work (pp. 145-159). Fernwood. 
Spolander, G., Engelbrecht, L., Martin, L., Strydom, M., Pervova, I., Marjanen, P., \& Adaikalam, F. (2014). The implications of neoliberalism for social work: Reflections from a six-country international research collaboration. International Social Work, 57(4), 301-312. https://doi. org/10.1177/0020872814524964

Stanley, T., \& Kelly, S. (2018). Practice leadership 'on purpose' - extending the reach of practice frameworks. Practice, 31(1), 41-56. doi:10.1080/09503153.2018.14 40286

Stark, C. (2018). The neoliberal ideology, its contradictions, the consequences and challenges for social work. Ljetopis Socijalnog Rada, 25(1), 39-64. https://doi. org/10.3935/ljsr.v25i1.196

Stats NZ. (2018). Non-profit institutions satellite account: 2018. file:///C:/Users/ashle/Downloads/non-profitinstitution-satellite-account-2018.pdf

Strier, R., \& Bershtling, O. (2016). Professional resistance in social work: Counterpractice assemblages. Social Work, 61(2), 111-118. https://doi.org/10.1093/sw/sww010

Taylor, M.F. (2002). Professional dissonance among social workers: The collision between values and job tasks in mental health practice (Doctoral dissertation). Retrieved from ProQuest Dissertations and Theses Database. (UMI No. 3055312)

Thorsen, D. E., \& Lie, A. (2006). What is neoliberalism? Politics in the Age of Neoliberalism, 1-21. http://folk.uio. no/daget/neoliberalism.pdf

Tsakiris, K. (2018). Max Weber's theory of rationalization: What it can tell us of modernity. Retrieved from https:// www.tremr.com/kyle-tsakiris/max-webers-theory-ofrationalization-what-it-can-tell-us-of-modernity

Wallace, J., \& Pease, B. (2011). Australian social work: Accommodation or resistance? Journal of Social Work, 11(2), 132-142. https://doi. org/10.1177/1468017310387318

Weber, M. (1946). The 'rationalization' of education and training. In H. H. Gerth \& C. Wright Mills (Eds.), From Max Weber: Essays in sociology (pp. 240-244. Oxford University Press.

Weiss-Gal, I., \& Welbourne, P. (2008). The professionalisation of social work: A cross national exploration. International Journal of Social Welfare, 17(4), 281-290.

Welbourne, P. (2011). Twenty-first century social work: The influence of political context on public service provision in social work education and service delivery. European Journal of Social Work, 14(3), 403-420. doi:10.1080/13691451003706670

Young, I. M. (1990). Justice and the politics of difference. Princeton University Press. 